\title{
Experiential learning through industrial placement in hospitality education: The meat in the sandwich
}

\author{
Evangelos Christou \\ International Hellenic University, Greece \\ Chryssoula Chatzigeorgiou \\ International Hellenic University, Greece
}

\begin{abstract}
The element of training is taken into account seriously by universities providing tourism education degrees, hence the development of "sandwich" undergraduate courses that incorporate a period of industrial placement aiming at the blending of theory with practical experience through experiential learning. The survey presented here was conducted in Greece and is objective was to evaluate the outcome of the supervised work experience by examining the views of undergraduate tourism and hospitality management students who completed their industrial placement period. Data were obtained through personal interviews and were of both qualitative and quantitative nature. The tentative results of the research, as described in this exploratory study, indicate some areas for concern and allows for conclusions to be drawn in relation to further improving and enhancing experiential learning.
\end{abstract}

Keywords: experiential learning, hospitality education, industrial placement period, tourism education, hospitality internships, work placement

JEL Classification: $I 23, L 83, M 12, O 15, Z 30$

Biographical note: Evangelos Christou is a Professor at the Department of Organisation Management, Marketing \& Tourism of the International Hellenic University, Greece (https://orcid.org/0000-0002-1950-5012). Chryssoula Chatzigeorgiou is an Associate Professor at the Department of Organisation Management, Marketing \& Tourism of the International Hellenic University, Greece (https://orcid.org/0000-0002-9348-992X). Corresponding author: Evangelos Christou, e-mail: echristou@ihu.gr

\section{INTRODUCTION}

Experiential learning is a critically important curriculum component of a degree program in hospitality management. Relevant sandwich degree courses (i.e., degrees that include a period of industrial placement or some type of supervised work experience) are specifically designed to prepare undergraduate students for particular employment fields in the hotel and catering industry. A period of industrial placement is fundamental to the sandwich structure; currently more than $93 \%$ of the hospitality and/or tourism management degree programs in North America and 95\% of similar courses in Europe require some type of supervised work experience (Foucar-Szocki, 1992; Chatzigeorgiou, 2017). Despite the fact that a large number of researchers around the world have investigated the value of supervised work experience or experiential learning through industrial placement (IP) in the past, it appears that this field of research presents a lot of controversy and requires additional study (Prinianaki-Tzorakoleftheraki, 1994; Eaton \& Christou, 1997; Oh \& Jeong, 2009). In addition, although much of the relevant research conducted internationally has been centered on the value of the students' industrial placement, studies have not investigated in depth the undergraduates' perspective of the supervised work experience period and the effect on their careers.

Undergraduate students at the BA in Tourism and Hospitality Management course at the International Hellenic University (in Greece) have to complete a six-month period of supervised work experience. The industrial placement is an indispensable component of the course and it has been claimed in the past to assist greatly the development of the 
students' knowledge and skills that were acquired during their studies (Christou, 1999; Christou, 2011). In addition, the IP is expected to influence positively both the continuation of the students' studies after they return to the university as well as to finding a permanent job after graduation (Rowe, 1995; Christou \& Sigala, 2000; 2001). The study described in this paper was aiming at investigating in depth the characteristics of these two issues. The specific objectives of the survey were: a) to investigate the contribution of supervised work experience to skill and knowledge development of undergraduate students of the BA in Tourism and Hospitality Management course; b) to explore student experience and reaction to IP; and c) to identify existing drawbacks and limitations of the IP period.

The IP element of an undergraduate requires significant investment of university resources (Fu \& Kapiki, 2016). All stakeholders related to these resources (students, host organisations from the hospitality and tourism industry, and educators) need to look for ways in which to achieve a justifiable return on investment (Chatzigeorgiou \& Christou, 2016). Therefore, the assessment of IP outcomes is essential for educators, universities, students and employers. In addition, the outcomes of the exploratory research described here could serve as stimuli for the implementation of more in-depth investigation of IP in the future. Apart from these benefits, the research described here is justified by its great potential in terms of practical use. Its outcomes may provide practical solutions to problems faced by the parties involved in the organisation and execution of the IP period and may provide usable information for further improving undergraduate programs in hospitality management.

\section{THEORETICAL FRAMEFORK}

\section{Nature of hospitality management education}

What is hospitality management education? Is it an applied or a professional discipline? There is no clear answer to what hospitality management education is; many researchers like Lundberg (1990), Ferreira (1992) and Samenfink (1992) have tried to define it by examining its educational nature. Based on the essence of the art of management Laesecke (1991) stated that the role of hospitality educational institutions must be to produce graduates who can think, lead, and solve problems. Casado (1992) and Defranco (1992) suggested that hospitality students must receive similar amount of professional concepts, general business principles, and liberal studies. Pavesic (1993) explained that "education must be thought as a journey, not a destination" and Pizam (1995), following a marketing-based approach to education, suggested that the ultimate customers (or recipients of benefits) in hospitality education are not the students of hotel and catering courses but the society in general and the hospitality and tourism industry.

The organisational structure of most hospitality firms is becoming horizontal rather than vertical in its basic shape, due to the widespread adoption of a leaner organizational structure requiring personnel multiskilling (Hodge, Anthony \& Gales, 1996; Christou, 2013). Hence, the hospitality graduates of the future will have to carry out a multidepartment manager role who bring together multiple competencies and multi-skilling (Williams \& DeMicco, 1998; Christou \& Nella, 2010).

It cannot be argued that hospitality management education is about the management of hotel and catering operations and organisations. Therefore, hospitality management education is a function of the acquisition of knowledge and skills about management in a way similar to that of other business administration courses; and, the acquisition of knowledge and competencies related to hotel and catering operations in a similar way to craft courses. In addition, higher education in hospitality should assist the student to develop communications and interpersonal "soft" skills and learn how to lead others (Goodman \& Sprague, 1991; Eaton \& Christou, 2000). The development of students' interpersonal skills is considered to be of paramount importance according to the views of the hospitality industry (Tas, 1988; Baum, 1990; Eaton \& Christou, 1997; 2006; 2010; Christou \& Karamanidis, 1999a, 1999b; Christou \& Sigala, 2002).

\section{Supervised work experience and industrial placement for hospitality students}

A common distinction between education and training is that establishments like universities mainly provide education while employers (organisations) usually provide vocational training. This distinction, which is the cornerstone of the traditional view towards education and training, suggests that education is for professionals and training is for the artisan and the unskilled (Baum, 1995). However, in today's environment, it is not realistic to impose an absolute distinction between education and training because they are not exactly two independent routes. Both the educational establishments (Fitzgerald \& Cullen, 1991; Ford \& LeBruto, 1995; Chatzigeorgiou et al., 2017; 2019) and employers (Partlow, 1996; Harris, 1997; Lyons \& Branston, 2006) around the world have adopted this approach.

The element of training is taken into account seriously by universities, hence the development of "sandwich" undergraduate courses that incorporate a period of industrial placement (Hogg, 1994; LeBruto \& Murray, 1994; Christou, 2003) aiming at the blending of theory with practical experience through experiential learning (DiMicelli, 1998; Nair \& George, 2016). It should be noted that, what is called in Europe as "industrial placement period" or more often as "supervised work experience" is usually called in North America as "internship". According to Petrillose and Montgomery (1998) the most popular of the experiential learning models in North America are the internships. However, research on internship programs has shown significant gaps in expectations between industry, students and hospitality educators (Downey \& DeVeau, 1988; Christou \& Kassianidis, 2002; Sigala \& Christou, 2003; 2007).

Student internships ranked third in the top twenty-seven components of quality in a hospitality undergraduate program (Pavesic, 1996; Valachis et al., 2008; 2009). The goal of experiential learning through a period of supervised work experience is for students to gain valuable work experience with an appropriate employer in the hospitality industry. Students have the opportunity through internships to develop analytical and leadership skills along with the concept of a productive worker (Cargill, 1996; Barron, 2008). 
In addition, students develop more realistic expectations of the professional world, faculty are up to date on trends and demands of the hospitality industry, and industry professionals are aware of the particular objectives of university education (Dresh \& Gregory, 1989; Benavides et al., 2013).

In fact, IP appears to bridge the gap between classroom or textbook theory and the practical side of applying it in a real hospitality setting (Busby \& Gibson, 2010). The supervised work experience period can assist students to learn how to cultivate communication, tolerance and interpersonal skills (Wisch, 1989; Chatzigeorgiou \& Simeli, 2017). The hospitality industry can assist in training the next generation of managers by working closely with educational institutions to appropriately blend theory and practice (Hill \& Reed, 1983; Chen et al, 2018).

Students' satisfaction with their IP in terms of satisfaction with their jobs as learning experiences was measured by Nelson (1997). At the same time, Emenheiser, Clayton and Tas (1997) empirically determined students' perceptions of the effectiveness of the IP phase. The work described here was aiming at the assessment of the IP period for students of the Department of Organisation Management, Marketing \& Tourism of the International Hellenic University, in Greece; students are required to undertake an industrial placement for six months. They have freedom of choice in terms of location and hospitality sector. However, the Department provides assistance to most students to find a host company.

\section{RESEARCH METHODOLOGY}

The survey presented here was conducted in Greece between April and October 2018. Its objective was to evaluate the outcome of the supervised work experience, by examining the views of BA in Tourism and Hospitality Management students at the International Hellenic University who completed their IP during the last six months. The data were obtained through personal interviews and were of both qualitative and quantitative nature. The quantitative information was gathered by using a structured questionnaire. To gather qualitative or "rich" information, depth interviews and focus groups were conducted using an informal discussion method with no structured questions.

The questionnaire was containing a variety of close-end multiple choice and dichotomous questions. While wording and laying it out, a lot of effort was spent in avoiding bias, using clear and concise words and avoiding ambiguous or leading questions (Christou et al., 2008). Additional consideration was given to the sequence of the questions, ensuring a logical flow by using the "funnel" technique (Chisnal, 1986). A pilot test was carried out in the $10 \%$ of the sample. The survey was anonymous, but limited data for the respondent were collected.

The chosen form of the depth interviews was that of "free response", giving the respondents a great deal of freedom in discussing their experiences and in answering questions arising from the general points of discussion. All interviews were conducted by adopting the "funnel" technique to the particular needs of qualitative research: the discussion started on the broadest possible level and gradually narrowed down through progressively more restricted channels. A list of points, which the interviews were going to cover, was prepared in advance. These points revolved around the following themes: the skills and knowledge gained from the IP; overall evaluation of the IP; the quality of the educational preparation for the reality of the workplace; other issues that were raised by the respondents. The researcher (without directly influencing the research) guided all interviews, so that all of the above themes were covered adequately.

The population under investigation consisted of all the students in the BA in Tourism and Hospitality Management course at the International Hellenic University that had completed their IP during the last six months (134 students in total). The sample was selected by using the census method and it consisted of the 134 students who undertook their IP at different hotels all over Greece. Hence, there was achieved a response rate of 100 percent.

\section{SURVEY FINDINGS AND DISCUSSION}

The most significant of the results obtained are presented in tables 1, 2, 3,4 and 5. It is widely accepted that students who have not worked in the hospitality industry may have premade perceptions of a glamorous industry (Woods, 1990); most students start their education with a positive attitude towards the hospitality industry (Purcell \& Quinn, 1995 Sigala \& Christou, 2006). The survey reported here attempted to discover if students became disillusioned and if so, whether they recovered. According to the outcome of the personal interviews, 69 per cent of the students admitted to some period of disillusionment ranging from a couple of weeks to 20 weeks, with an average period of 4.8 weeks. The major reasons suggested for the disillusionment were being away from friends and relatives and experiencing a stressful and exhausting work environment. 48 per cent of the students did recover but 16 per cent did not and therefore completed their IP period in a state of considerable disillusionment.

Table 1: Development of students' key management competencies during their studies (before the IP period)

\begin{tabular}{|c|c|c|c|}
\hline \multirow{2}{*}{$\begin{array}{l}\text { A. Key management } \\
\text { competencies }\end{array}$} & \multicolumn{3}{|c|}{$\begin{array}{c}\text { Development of competencies } \\
\text { during studies }\end{array}$} \\
\hline & $\begin{array}{l}\text { High } \\
(\%)\end{array}$ & $\begin{array}{l}\text { Medium } \\
(\%)\end{array}$ & $\begin{array}{c}\text { Low } \\
(\%)\end{array}$ \\
\hline $\begin{array}{l}\text { Solving customer } \\
\text { problems }\end{array}$ & 5 & 20 & 75 \\
\hline $\begin{array}{l}\text { Human resource } \\
\text { management skills }\end{array}$ & 24 & 56 & 20 \\
\hline Oral communication & 15 & 18 & 67 \\
\hline $\begin{array}{l}\text { Basic management } \\
\text { principles }\end{array}$ & 32 & 38 & 30 \\
\hline $\begin{array}{l}\text { Positive peer relationships } \\
\text { Professional standards }\end{array}$ & 21 & 57 & 22 \\
\hline Knowledge of ethics & 8 & 13 & 78 \\
\hline Written communication & 12 & 16 & 72 \\
\hline Professional appearance & 48 & 33 & 19 \\
\hline and poise & 0 & 8 & 92 \\
\hline
\end{tabular}

All of the interviewees expressed the view that the industrial placement was, to an extent, an effective way of putting their 
newly acquired knowledge and skills to a real-life test. The majority of the students ( $88 \%$ ) agreed that by the end of the placement phase they had a better understanding of the hospitality and tourism industry and of the potential of their future careers in it. They also added that although prior to their IP they were not psychologically prepared for formal work responsibilities, they gained valuable experience from being in a real-life working environment.

Table 2: Contribution of IP period to the further development of key management competencies

\begin{tabular}{|l|c|c|c|}
\hline \multirow{2}{*}{$\begin{array}{l}\text { B. Key management } \\
\text { competencies }\end{array}$} & \multicolumn{3}{|c|}{$\begin{array}{c}\text { Contribution of supervised work } \\
\text { experience }\end{array}$} \\
\cline { 2 - 4 } & $\begin{array}{c}\text { High } \\
(\%)\end{array}$ & $\begin{array}{c}\text { Medium } \\
(\%)\end{array}$ & $\begin{array}{c}\text { Low } \\
(\%)\end{array}$ \\
\hline $\begin{array}{l}\text { Solving customer } \\
\text { problems }\end{array}$ & 46 & 48 & 6 \\
$\begin{array}{l}\text { Human resource } \\
\text { management skills }\end{array}$ & 25 & 63 & 12 \\
$\begin{array}{l}\text { Oral communication } \\
\begin{array}{l}\text { Basic management } \\
\text { principles }\end{array}\end{array}$ & 64 & 27 & 8 \\
$\begin{array}{l}\text { Positive peer relationships } \\
\text { Professional standards }\end{array}$ & 35 & 58 & 15 \\
$\begin{array}{l}\text { Knowledge of ethics } \\
\begin{array}{l}\text { Written communication } \\
\text { Professional appearance } \\
\text { and poise }\end{array}\end{array}$ & 80 & 20 & 21 \\
\hline
\end{tabular}

The students' opinion was that they managed to improve greatly their practical skills in hotel and catering operations during the placement period. Another area of satisfaction was the development of the students' soft skills; soft skills are human relations associated competencies (Cho, 2006). The areas that were usually improved were time management, discipline, organisational skills, and team working. They also wished they could have developed further their skills in problem solving, leadership and motivation, and interviewing techniques.

Notes for tables 1, 2, \& 3:

a) Respondents could choose more than one alternative answer

b) Percentages are rounded to nearest non decimal number

c) The competencies examined are considered as most important for hotel

manager trainees LeBruto \& Murray, 1994).

Notes for the tables $4 \& 5$ :

a) Respondents could choose only one alternative answer

b) Percentages are rounded to nearest non decimal number

The main criticisms about the industrial placement period were focused on working conditions and the lack of development of management skills. It appeared to be a common view that the working conditions provided by the "hosting" organisations were not good enough, especially for those who did their placement in hotels that operate on a seasonal basis. The most widely mentioned sources of disappointment included: underpayment, hours of work were too long and, the feeling that they were seen by companies as cheap labour or as a burden. However, the vast majority of the interviewees (78\%) admitted that the structuring of the placement was good regarding hotel operations skills. However, almost all of the respondents remained in entrylevel positions throughout their placements and had no chance of developing their management and administrative skills. Even the development of supervisory skills was kept to a minimum.

Table 3: Contribution of IP period to the development of key personal skills

\begin{tabular}{|l|c|c|c|}
\hline \multirow{2}{*}{ Key personal skills } & \multicolumn{3}{|c|}{$\begin{array}{c}\text { Contribution of supervised work } \\
\text { experience }\end{array}$} \\
\cline { 2 - 4 } & $\begin{array}{c}\text { High } \\
(\%)\end{array}$ & $\begin{array}{c}\text { Medium } \\
(\%)\end{array}$ & $\begin{array}{c}\text { Low } \\
(\%)\end{array}$ \\
\hline $\begin{array}{l}\text { Personal initiative } \\
\text { Guest interaction }\end{array}$ & 67 & 56 & 12 \\
$\begin{array}{l}\text { Ability to work with } \\
\text { others }\end{array}$ & 24 & 73 & 12 \\
$\begin{array}{l}\text { Linguistic ability } \\
\text { Self-reliance }\end{array}$ & 15 & 47 & 38 \\
$\begin{array}{l}\text { Self-discipline } \\
\text { Hotel operation skills } \\
\text { (front office) }\end{array}$ & 28 & 39 & 23 \\
$\begin{array}{l}\text { Hotel operation skills } \\
\text { (housekeeping) }\end{array}$ & 14 & 84 & 8 \\
$\begin{array}{l}\text { Food and beverage } \\
\text { service skills }\end{array}$ & 65 & 22 & 53 \\
$\begin{array}{l}\text { Food and beverage } \\
\text { production skills } \\
\text { Application of theory to } \\
\text { practice }\end{array}$ & 24 & 62 & 48 \\
\hline
\end{tabular}

The students expressed the view that the combination of poor working conditions and the lack of management experience resulted in reduced motivation and low moral. Six of the interviewees mentioned that three to six months after their placement period started, they were anxiously waiting for the completion of the phase and that they were considerably demotivated to pursue a future career in the hospitality industry. These results are supported by the findings of the questionnaire survey (table 4). However, these results seem to contradict the findings of previous studies (Leslie, 1991; N.S.S.G., 1994; Yilmaz, 2018). In addition, Brennen and McGeevor (1985) and Sigala \& Christou (2014) argued that studying a vocational degree greatly increases the chance of employment in that field.

The advantages of the supervised work experience to students have internationally been described in the past (RISE, 1985; Sigala \& Christou, 2002); the results of the present survey tend to conform to the major findings of other authors (West \& Jameson, 1990; Leslie, 1991; Christou, 2002). The IP period seems to have been a beneficial experience for most students as the results at table 5 present. The vast majority of the respondents (eighty-five per cent) described their industrial placement as a very positive or positive experience. However, it would be interesting to investigate in the future the deeper reasons behind the negative responses given by the fifteen per cent of the students.

The contribution of the supervised work experience to the development of management competencies seems to have been quite important (table 2). According to the vast majority 
of the students, the IP period contributed up to a medium or high level to the development of nine key management competencies. This level was considerably higher than that of their period of traditional study at the university (table 1).

Table 4: Relationship between IP period \& future career preferences

\begin{tabular}{|c|c|}
\hline Future career preferences & Answers (\%) \\
\hline $\begin{array}{l}\text { The supervised work experience period } \\
\text { reinforced my desire to work in the } \\
\text { hospitality industry after my graduation. } \\
\text { The supervised work experience period } \\
\text { made me sceptical about working in the } \\
\text { hospitality industry after my graduation. } \\
\text { After the supervised work experience } \\
\text { period I took the decision not to work in the } \\
\text { hospitality industry after my graduation. }\end{array}$ & 33 \\
\hline
\end{tabular}

Therefore, it is reasonable to assume that management competencies are better developed under a real-life work environment than at the classrooms of an educational establishment. This view is further supported by the findings presented at table 3; most of the students that went through the industrial placement period rated as high or medium the contribution of their work experience to the development of eleven key personal skills. In addition, the findings reported here are strongly supported by other studies (Hogg, 1994; Farmaki, 2018) which emphasised that, in order to ensure the development of the students' skills and competencies, all hospitality management schools or undergraduate programmes have to include some form of practicum or internship.

Table 5: Overall assessment of the IP period

\begin{tabular}{|l|c|}
\hline \multicolumn{1}{|c|}{ Future career preferences } & Answers (\%) \\
\hline Very positive experience & 22 \\
Positive experience & 63 \\
Negative experience & 10 \\
Very negative experience & 5 \\
\hline
\end{tabular}

The findings suggested that as a result of the supervised work experience more than half of the students could be lost to the hospitality industry. Perhaps this should be a source for concern for both the education and the industry. It is essential to find solutions for this problem and therefore to optimise the benefits for the students and the industry. The core of the IP period consists by a group of stakeholders: the student, the host organisation and the educational establishment. It seems that each of these three should amend and enhance some parts of their approach in order to produce the maximum benefit for each one.

\section{CONCLUSIONS}

The tentative results of the research of a small sample, as described in this exploratory study, indicate some areas for concern and allows for the following conclusions to be drawn:

- The major benefits of the IP period to the students include: a more complete knowledge of the tourism products and of the diversity of the hospitality industry; development of the individual by improving his/hers personal skills; development of professional skills; and, development of key management competencies. However, the development of hospitality operations skills was significantly higher than the development of management skills.

- The students had the chance to identify career paths within different sectors of the hospitality industry. In addition, it can be suggested that there is a positive relationship between the sector of the IP and the sector intended to be chosen after graduation for full-time employment.

- It may be necessary for the educational establishments in the future to examine carefully the selection process of industrial placement hosting organisations.

- There is evidence suggesting that the school must improve the students' psychological preparation for the IP period in a real-work environment.

- By critically examining the use of IP period as a teaching and learning tool a better understanding of its advantages, disadvantages and relative value was developed.

- The increased personal interaction with a large number of students as a requirement of the research methodology resulted to establishing closer links with them and to a better understanding of their needs, beliefs and attitudes towards their studies and their supervised work experience periods.

Finally, alternative courses of action, based on the research findings, can be proposed in order to improve the effectiveness and efficiency of the supervised work experience as an educational tool. These proposals might be based on the future results of a more detailed examination of the issues identified in this survey. The issues for further investigation could include: the requirements and the techniques necessary for better psychological preparation of the students before the supervised work experience; the improvement of the selection process of potential host organisations; ways for establishing closer links between the faculty and the hospitality industry; and ways for improving the relationship and the understanding between the student body and the faculty.

\section{REFERENCES}

Barron, P. (2008). Education and talent management: Implications for the hospitality industry. International Journal of Contemporary Hospitality Management, 20(7), 730-742. doi:10.1108/09596110810897583.

Baum, T. (1990) Competencies for hotel management: industry expectations of education. International Journal of Contemporary Hospitality Management, 2(4), 13-15.

Baum, T. (1995) Managing Human Resources in the European Hospitality Industry: A Strategic Approach. London: Chapman \& Hall. 
Benavides, A.D., Dicke, L.A., \& Holt, A.C. (2013). Internships adrift? Anchoring internship programs in collaboration. Journal of Public Affairs Education, 325-353. doi:10.1080/15236803.2013.12001736

Brennen, J. \& McGeevor, P.A. (1985) Higher Education and the Labor Market, CNAA Graduates: Their Experiences and Views Twelve Months After Graduation. London: Council for National Academic Awards Development Services Unit Paper.

Busby, G., \& Gibson, P. (2010). Tourism and hospitality internship experiences overseas: A British perspective. Journal of Hospitality, Leisure, Sport and Tourism Education, 9(1), 4-12. doi:10.3794/johlste. 91.244

Casado, M. A. (1992) Higher education hospitality schools: meeting the needs of the industry. Hospitality and Tourism Educator, 4(2), 41-44.

Cargill, C. (1996) Developing the ideal internship: what are your thoughts, part two. Annual CHRIE Conference. Washington, D. C., August.

Chatzigeorgiou, C. (2017). Modelling the impact of social media influencers on behavioural intentions of millennials: The case of tourism in rural areas in Greece. Journal of Tourism, Heritage \& Services Marketing, 3(2), 25-29. http://doi.org/10.5281/zenodo.1209125.

Chatzigeorgiou, C. \& Christou, E. (2016). Destination branding and visitor brand loyalty: Evidence from mature tourism destinations in Greece. Tourismos: An International Multidisciplinary Journal of Tourism, Vol. 11, No. 5, pp. 102123

Chatzigeorgiou, C., Christou, E. \& Simeli, I. (2017). Delegate satisfaction from conference service quality and its impact on future behavioral intentions. 5th International Conference on Contemporary Marketing Issues, ICCMI, June 21-23, 2017 Thessaloniki, Greece, pp. 532-544.

Chatzigeorgiou, C., Christou, E. \& Simeli, I. (2019). Confidence and loyalty for agrotourism brands: The Lesvos paradigm. Tourismos: An International Multidisciplinary Journal of Tourism, Vol. 14, No. 1, pp. 151-166.

Chatzigeorgiou, C. \& Simeli, I. (2017). Perception of service quality in agrotourism accommodations: Impact on guest loyalty and re-visit intentions. Journal of Tourism, Heritage \& Services Marketing, 3(1), http://doi.org/10.5281/zenodo.401375.

Chen, T.L., Shen, C.C., \& Gosling, M. (2018). Does employability increase with internship satisfaction? Enhanced employability and internship satisfaction in a hospitality program. Journal of Hospitality, Leisure, Sport \& Tourism Education, 22, 88-99. doi:10.1016/j.jhlste.2018.04.001.

Cho, M. (2006). Student perspectives on the quality of hotel management internships. Journal of Teaching in Travel \& Tourism, 6(1), 61-67. doi:10.1300/J172v06n01 04.

Christou, E.S. (1999). Hospitality management education in Greece An exploratory study. Tourism Management, 20(6), 683-691. https://doi.org/10.1016/S0261-5177(99)00039-4.

Christou, E. (2002). Revisiting competencies for hospitality management: Contemporary views of the stakeholders. Journal of Hospitality \& Tourism Education, 14(1), 25-32. https://doi.org/10.1080/10963758.2002.10696721.

Christou, E. (2003). On-line buyers' trust in a brand and the relationship with brand loyalty: the case of virtual travel agents. Tourism Today, Vol. 3, No.1, pp.95-106.

Christou, E. (2006). A qualitative analysis of consumer attitudes on adoption of online travel services. Tourism: An International Interdisciplinary Journal, 54(4), 323-332.

Christou, E. (2010). Investigating attitudes towards mobile commerce for travel products. Tourism: An International Interdisciplinary Journal, 58(1): 7-18.
Christou, E. (2011). Exploring the impact of visitor satisfaction on loyalty towards a specific destination. Acta Turistica, Vol.23, No.1, pp.1-25.

Christou, E. (2013). Exploring brand confusion through hotel adverts. Tourismos: An International Multidisciplinary Journal of Tourism, Vol.8, No.3, pp.151-163.

Christou, E. \& Karamanidis, I. (1999a) Hospitality management competencies revisited: industry and graduates contemporary perspectives. Joint IAHMS/CHME/EuroCHRIE Conference Proceedings, Guildford: University of Surrey, 1, 52-68.

Christou, E. \& Karamanidis, I. (1999b). Enhancing competitiveness in the hospitality industry: Revisiting Porter's generic competitive strategies in Greece, The Tourist Review, Vol. 54 No. 1, pp. 42-50. https://doi.org/10.1108/eb058295.

Christou, E. \& Kassianidis, P. (2002). Examining the adoption of eshopping for travel services: determinants of consumers' perceptions, in Wober, A., Frew, A. and Hitz, M. (Eds), Information and Communication Technologies in Tourism 2002, Springer-Verlag, Vienna, pp. 187-96.

Christou, E. \& Nella, A. (2010). A review of wine tourism research from 1995 to 2010: Analysis of 110 contributions. Journal of Hospitality \& Tourism, 8(1), 112-123.

Christou, E.S., and Sigala, M. (2001). Professional Development in Hospitality and Tourism Education: A Strategy for the 21st. Century. International Journal of Tourism Research, 3(4), pp. 328-30. https://doi.org/10.1002/jtr.317.

Christou, E. \& Sigala, M. (2000). Exploiting Multimedia for Effective Hospitality Education. EuroCHRIE Spring Conference Proceedings. Dublin, Ireland: Dublin Institute of Technology.

Christou, E. \& Sigala, M. (2002). Innovation in Hospitality and Tourism Education. International Journal of Tourism Research, 4(1), 65-67. https://doi.org/10.1002/jtr.330.

Christou, E., Valachis, I. and Anastasiadou, C. (2008). Research methodology in hospitality industry: the role of the inquiry paradigms, available at: www.ul.edu.lb/fthm/papers/ 3rd\%20Axis/Methodology\%20greece.doc

Chisnal, P. M. (1986) Marketing Research. London: McGraw-Hill.

Defranco, A. L. (1992) Back to the basics: humanism in education. Hospitality and Tourism Educator, 4(3), 71-72.

DiMicelli, P. (1998) Blending theory \& practical experience: a hands-on approach to educating hospitality managers. Journal Hospitality \& Tourism Education, 10(1), 32-36.

Downey, J. F. \& DeVeau, L. (1988) Hospitality internships: an industry view. The Cornell Hotel and Restaurant Administration Quarterly, 29(3), 18-20.

Dresh, C. \& Gregory, S. (1989) Educators must pursue industry relationships. Nations Restaurant News. April 17th, 24-31.

Eaton, J. \& Christou, E. (1997) Hospitality management competencies for graduate trainees: employers' views. Journal of European Business Education, 7(1), 60-68.

Eaton, J. \& Christou, E. (2000). Management competencies for graduate trainees. Annals of Tourism Research, 27(4), 10581062. https://doi.org/10.1016/S0160-7383(99)00129-2

Farmaki, A. (2018). Tourism and hospitality internships: A prologue to career intentions? Journal of Hospitality, Leisure, Sport \& Tourism Education, 23, 50-58. doi:10.1016/j.jhlste.2018.06.002.

Ferreira, R. R. (1992) A review of case analysis and simulation for use in hospitality management education. Hospitality and Tourism Educator, 4(2), 16-20.

Fitzgerald, M. J. and Cullen, T. P. (1991) Learning through a "real world" experience. The Cornell Hotel and Restaurant Administration Quarterly, August, 85-88.

Ford, C. R. and LeBruto, S. M. (1995) Management education in the USA: how much practical hotel management education is necessary? International Journal of Contemporary Hospitality Management, 7(5), i-iv. 
Foucar-Szocki, R. (1992) Experiential learning-internships, externships, co-ops, practicums: a state of the art (Abstract). Proceedings of the 1992 Annual CHRIE Conference, 269-270.

$\mathrm{Fu}$, J. \& Kapiki, S.T. (2016). Reengineering knowledge for etourism and hospitality curricula. Journal of Tourism, Heritage \& Services Marketing, 2(2), 23-32. http://doi.org/10.5281/zenodo.376345.

Goodman, J. R. and Sprague, L. G. (1991) The future of hospitality education: meeting industry's needs. Cornell Hotel and Restaurant Administration Quarterly, 32(2), 66-69.

Harris, K. J. (1996) Opinions of training methods used in the hospitality industry: a call for review. International Journal of Hospitality Management, 14(1), 79-96.

Haywood, K. M. (1989) A radical proposal for hospitality and tourism education. International Journal of Hospitality Management, 8(4), 259-260.

Hill, T. \& Reed, V. (1983) The co-op opportunity. The Cornell Hotel \& Restaurant Administration Quarterly, 25(2), 46-49.

Hodge, B. J., Anthony, W. P. \& Gales, L. M. (1996) Organizational Theory. Upper Saddle River, NJ: Simon \& Schuster, 42-45.

Hogg, C. (1994) A foretaste of work. Human Resources, Spring, 102-106.

Laesecke, H. (1991) Meeting the industry needs. The Cornell Hotel and Restaurant Administration Quarterly, August, 112-119.

LeBruto, S. M. and Murray, K. T. (1994) The educational value of "captive hotels". The Cornell Hotel and Restaurant Administration Quarterly, August, 72-79.

Leslie, D. (1991) The hospitality industry, industrial placement and personnel management. Service Industries Journal, 11(1), 6374.

Lyons, A. \& Branston, C. (2006). Cross cultural change, adjustment and culture shock: UK to USA. Tourism: An International Interdisciplinary Journal, 54(4), 355-365. Available at: https://hrcak.srce.hr/161568.

Lundberg, C. C. (1990) A note on targeting hospitality education. Hospitality and Tourism Educator, 3(1), 36-37.

Nair, R. \& George, B.P. (2016). E-learning adoption in hospitality education: An analysis with special focus on Singapore. Journal of Tourism, Heritage \& Services Marketing, 2(1), 313. http://doi.org/10.5281/zenodo.376329.

National Statistical Service of Greece (1994) School of Tourism Professions. Athens: Survey on Graduates' Routes Report (in Greek).

Nelson, A. (1997) Hospitality internships: the effects of job dimensions on student satisfaction. Proceedings of the 1997 Annual CHRIE Conference. Providence, Rhode Island, 133138.

Oh, H. and Jeong, M. (2009) A self-service technology adoption model in the resort hotel environment, paper presented at the 2009 I-CHRIE Conference, San Francisco, CA, 29 July-1 August.

Partlow, C. G. (1996) Human resources practices of TQM hotels. The Cornell Hotel and Restaurant Administration Quarterly, 37(1), 67-77.

Pavesic, D. V. (1993) Hospitality education 2005: curricular and programmatic trends. Hospitality Research Journal, 17(1), 285294.

Pavesic, D. (1996) determinants of quality in hospitality undergraduate programs. Hospitality \& Tourism Educator, 8(2/3), 96-103.

Petrillose, M. J. and Montgomery, R. (1998) An exploratory study of internship practices in hospitality education and industry's perception of the importance of internships in hospitality curriculum. Journal of Hospitality and Tourism Education, 9(4), 46-51.

Pizam, A. (1995) Who is the customer in hospitality education? International Journal of Hospitality Management, 14(3), 215216.
Prinianaki-Tzorakoleftheraki, E. (1994) Tourism and hospitality education in Greece: tertiary public sector, with emphasis on the "tourism industries" course of the Technological Educational Institutions. Unpublished MSc dissertation. Guildford: University of Surrey, England.

Purcell, K and Quinn, J. (1995) Hospitality Management Education and Employment Trajectories. Oxford: School of Hotel and Catering Management, Oxford Brookes University.

RISE, (1985) Assessment of the Costs and Benefits of Sandwich Education. London: Committee on research into sandwich education, Department of Education and Science.

Rowe, M. (1995) From classroom to boardroom. Lodging Hospitality, 51(10), 36-38.

Samenfink, W. H. (1992) A rebuttal: careerism and general education revisited in the hospitality curriculum. Hospitality and Tourism Educator, 4(2), 50-52.

Sigala, M., \& Christou, E. (2002). Use of internet for enhancing tourism and hospitality education: Lessons from Europe. In Information and Communication Technologies in Tourism 2002: Proceedings of the International Conference in Innsbruck, Austria, 2002 (229-238). Springer: Verlag Wien.

Sigala, M. \& Christou, E. (2002). The transformative power of ecommerce on hotel brands. Proceedings of the Annual European Council for Hotel, Restaurant and Institutional Education (Euro-CHRIE) Conference, Cross-cultural Challenges in the Tourism Industry, Barcelona, Spain.

Sigala, M. \& Christou, E. (2003). Enhancing and Complementing the Instruction of Tourism and Hospitality Courses Through the Use of On-line Educational Tools, Journal of Hospitality \& Tourism Education, 15:1, 6-15, DOI: 10.1080/10963758.2003.10696755.

Sigala, M. \& Christou, E. (2006). Investigating the impact of ecustomer relationship management on hotels' website service quality. $\quad$ ECIS $2006 \quad$ Proceedings. 118. http://aisel.aisnet.org/ecis2006/118.

Sigala, M. \& Christou, E. (2007). Exploiting Web 2.0 in open and distance education: Developing personalised and collaborative learning environments. In A. Lionarakis (ed.), Proceedings of the 4th International Conference on Open and Distance Learning-ICODL 2007 (pp.181-195). Athens: Propombos.

Sigala, M., \& Christou, E. (2014). Social computing in travel, tourism and hospitality. Computers in Human Behavior, 30, 771-772. doi:10.1016/j.chb.2013.11.003.

Tas, R. (1988) Teaching future managers. The Cornell Hotel and Restaurant Administration Quarterly, 29(2), 58-64.

Tsartas, P. (1998) Un cadre d' analyse des relations sociales et des caracteristiques de la rencontre touristes-autochtones: le cas de la Grece. AIEST Revue de Tourisme, 4, 47-55.

Valachis, I., Christou, E., Maroudas, L., \& Sigala, M. (2008). Assessment of training quality in hospitality industry: an exploratory model. In 26th EUROCHRIE Congress "Building a Legacy, Living the Dream (Vol. 2020).

Valachis, I., Christou, E., Sigala, M. and Maroudas, L. (2009). Developing human resources' skills and knowledge in tourism and hospitality industry through the determination of quality of training program. Tourism and Hospitality Management, 15(1), pp.61-72.

West, J. and Jameson, S. (1990) Supervised work experience in graduate employment. International Journal of Contemporary Hospitality Management, 2(2), 29-32.

Williams, J. \& DeMicco, F. J (1998) The challenge of multidepartment management for future hospitality graduates. Journal of Hospitality \& Tourism Education, 10(1), 13-17.

Wisch, R. (1989) Stressing the practical side of training hospitality students through internships. Hospitality Education \& Research Journal, 13, 483. 
Woods, R.C. (1990) The image of the hotel in popular literature: a preliminary statement. International Journal of Hospitality Management, 9(1), 5-8.

Yilmaz, O.Z. (2018). Revisiting Employee - Guest Interactions in Hotels: An Analysis of Critical Incidents. Journal of Tourism, Heritage \& Services Marketing, 4(2), 17-23. http://doi.org/10.5281/zenodo.1490400.

SUBMITTED: FEBRUARY 2019

REVISION SUBMITTED: MAY 2019

ACCEPTED: JULY 2019

REFEREED ANONYMOUSLY

PUBLISHED ONLINE: 24 OCTOBER 2019 